\title{
Circulating Tumour DNA for Early Diagnosis of Pancreatic Ductal Adenocarcinoma
}

\author{
Ayu Hutami Syarif \\ Research and Development Department, Indonesia National Cancer Center - Dharmais Cancer Hospital, Jakarta, Indonesia
}

\section{ARTICLE INFO}

Received : 06 December 2020

Reviewed : 10 January 2021

Accepted : 21 May 2021

Keywords:

circulating tumor DNA, liquid biopsy, pancreatic neoplasms

\begin{abstract}
Background: Pancreatic ductal adenocarcinoma (PDAC) has been deathly cancer arising from pancreatic cells. Despite the improvement in the standard of diagnosis, most patients seek medical care in the late stage. Due to the aggressiveness of the disease, it is therefore imperative to detect the early lesion for a better outcome.
\end{abstract}

Methods: We identified 416 articles relevant to circulating tumor DNA (ctDNA) and PDAC using predefined keywords in PubMed, PubMed Central, and Cochrane Library from January 1, 2011, to January 1, 2021 (10 years). Firstly, we screened the titles and abstracts, and 63 articles were included. Then, we screened those articles for the full-text version and included only 8 articles fulfilling our inclusion criteria. All steps were reviewed by the author.

Results: The presence of ctDNA in the blood reflects the occurrence of the pancreatic cancerspecific mutation in the primary tumor. The detection of KRAS mutation in ctDNA and tumor samples is highly consistent. The number of positive findings in early-stage patients is low, in line with the low ctDNA concentration measured. However, the combination of KRAS detected in ctDNA and other biomarkers showed prominent results with higher sensitivity and specificity.

Conclusions: ctDNA is a promising tool for early detection of PDAC. Despite its low positivity rate in certain studies, it is considerably concordant with the primary tumor. Future improvement in the technique application is required to overcome the issue of low DNA concentration in circulation.

\section{INTRODUCTION}

Pancreatic ductal adenocarcinoma (PDAC) is a malignancy that occurs in cells lining the pancreatic duct. It is the seventh most common cause of cancerrelated deaths globally, with a survival rate of only $5 \%[1,2]$. Generally, the standard diagnosis approach uses tissue biopsy following non-invasive tests such as imaging and serum markers. Unfortunately, $50 \%$ of PDAC present with metastasis [2], providing less probability for surgery as the primary treatment. Also, diagnostic modality such as imaging is unable to detect small tumor lesion. Given the aggressiveness and frequent late presentation, it is necessary to develop a robust tool to capture early lesions in PDAC. This review will argue that circulating tumor DNA (ctDNA) carrying specific gene mutations can be deployed to early diagnose PDAC.

\section{METHODS}

\section{Search Strategies}

The researcher used several medical subject headings (MeSH) to search the appropriate articles. These include "liquid biopsy", "cell-free tumor DNA", "cell-free DNA", "circulating tumor DNA", and "carcinoma, pancreatic ductal" from three databases (Pubmed, Pubmed Central, Cochrane Library) from January 1, 2011, and January 1, 2021 (Table 1). The articles were selected when all the inclusion criteria had been met. They are pancreatic ductal adenocarcinoma (population), patients with stage I and/or II (interest), patients with stage III/IV cancer (comparison), detection rate (outcome), and interventional and cohort observational study (study design).

\section{Data Extraction}

Details that were included from each article were the author's name, the country of the study population, sample size, the method of mutation detection, gene 
mutation identified, and the outcomes. We performed the Newcastle-Ottawa Validity test to appraise the articles, and the result is shown below (Table 2 ).

\section{Quality Assessment and Evidence}

We used the Newcastle-Ottawa Quality Assessment Scale to assess the methodological quality of the selected nonrandomized studies with three aspects to rate, including selection, comparability, and outcome. The result of the assessment (good, fair, and poor) was based on the number of stars in each aspect. A "good" study scored 3 or 4 stars in the selection, 1 or 2 stars in comparability, and 2 or 3 stars in outcomes; a "fair" study scored 2 stars in the selection, 1 or 2 stars in comparability, and 2 or 3 stars in outcomes; a "poor" study scored 0 or 1 star in the selection, or 0 stars in comparability, or 0 or 1 star in outcomes.

\section{RESULTS}

\section{Literature Search Results}

We identified a total of 416 articles from three big databases (Pubmed, Pubmed Central, and Cochrane Library). All articles were screened using the predefined criteria, and 20 duplicate articles were removed. We excluded 388 articles due to the unavailability of earlystage cases. For the final stage, only 8 articles were included in the review. The search workflow is illustrated in Figure 1.
Circulating Tumor DNA: Opportunity and Challenges

It is a natural phenomenon that tumor cells release DNA known as ctDNA during necrosis or apoptosis (Figure 2). This short fragment DNA represents the primary tumor genetic landscape, as shown in its high concordance rate. Above all, ctDNA serves as a promising diagnostic tool for PDAC. Despite the practicability in the sampling method and the high accuracy, some potential challenges need to be addressed before its implementation into the clinical setting.

\section{High Concordance Rate}

There is a high concordance between ctDNA and tissue DNA in early-stage disease (Table 3). Concordance is defined as the same mutation found in both tumor tissue and plasma. Four ctDNA studies reported a 74.3$82 \%$ concordance in detecting KRAS mutation [4-6]. Their findings are extremely relevant as KRAS is the most frequent mutation in PDAC. Furthermore, the second most common mutation in PDAC, TP53, was also reported to be abundantly found in ctDNA, with a concordance rate even higher than that of KRAS (61\%) [7]. Conversely, several reports also outlined a low concordance rate $(20 \%-35 \%)[5,8,9]$. Of note, high concordance studies involved more metastatic cases, which may explain another source of KRAS mutant ctDNA. This is evident in Patel et al. [7] study, showing that metastatic cases' concordance rate was higher than that with localized tumors (72\% vs. 39\%). However,
Table 1. Literature search strategy

\begin{tabular}{|c|c|c|}
\hline Database & Keyword & Result \\
\hline Pubmed & $\begin{array}{l}\text { ("liquid biopsy" OR "cell free tumor dna" OR "cell free dna" OR "circulating } \\
\text { tumor dna") AND ("carcinoma, pancreatic ductal"[MeSH Terms] }\end{array}$ & 63 \\
\hline $\begin{array}{l}\text { Pubmed } \\
\text { Central }\end{array}$ & $\begin{array}{l}\text { ("liquid biopsy" OR "cell-free tumor DNA" OR "cell-free DNA" OR "circulating } \\
\text { tumor DNA") AND ("carcinoma, pancreatic ductal"[MeSH Terms] }\end{array}$ & 71 \\
\hline $\begin{array}{l}\text { Cochrane } \\
\text { Library }\end{array}$ & $\begin{array}{l}\text { "liquid biopsy" OR "cell-free tumor DNA" OR "cell-free DNA" OR "circulating } \\
\text { tumor DNA" AND carcinoma, pancreatic ductal }\end{array}$ & 282 \\
\hline
\end{tabular}

Table 2. The Newcastle-Ottawa quality assessment result

\begin{tabular}{lllll}
\hline Study & Selection & Comparability & Outcome & Results \\
\hline Cohen 2017 [5] & 3 & 1 & 2 & Good \\
Nakano 2018 [11] & 2 & 1 & 3 & Fair \\
Hadano 2016 [4] & 2 & 1 & 2 & Fair \\
Patel 2019 [7] & 3 & 1 & 2 & Good \\
Groot 2019 [22] & 3 & 1 & 2 & Good \\
Kim 2018 [6] & 2 & 1 & 2 & Fair \\
Takai 2015 [10] & 3 & 1 & 3 & Good \\
Shiwei 2020 [23] & 3 & 1 & 2 & Good \\
\hline
\end{tabular}




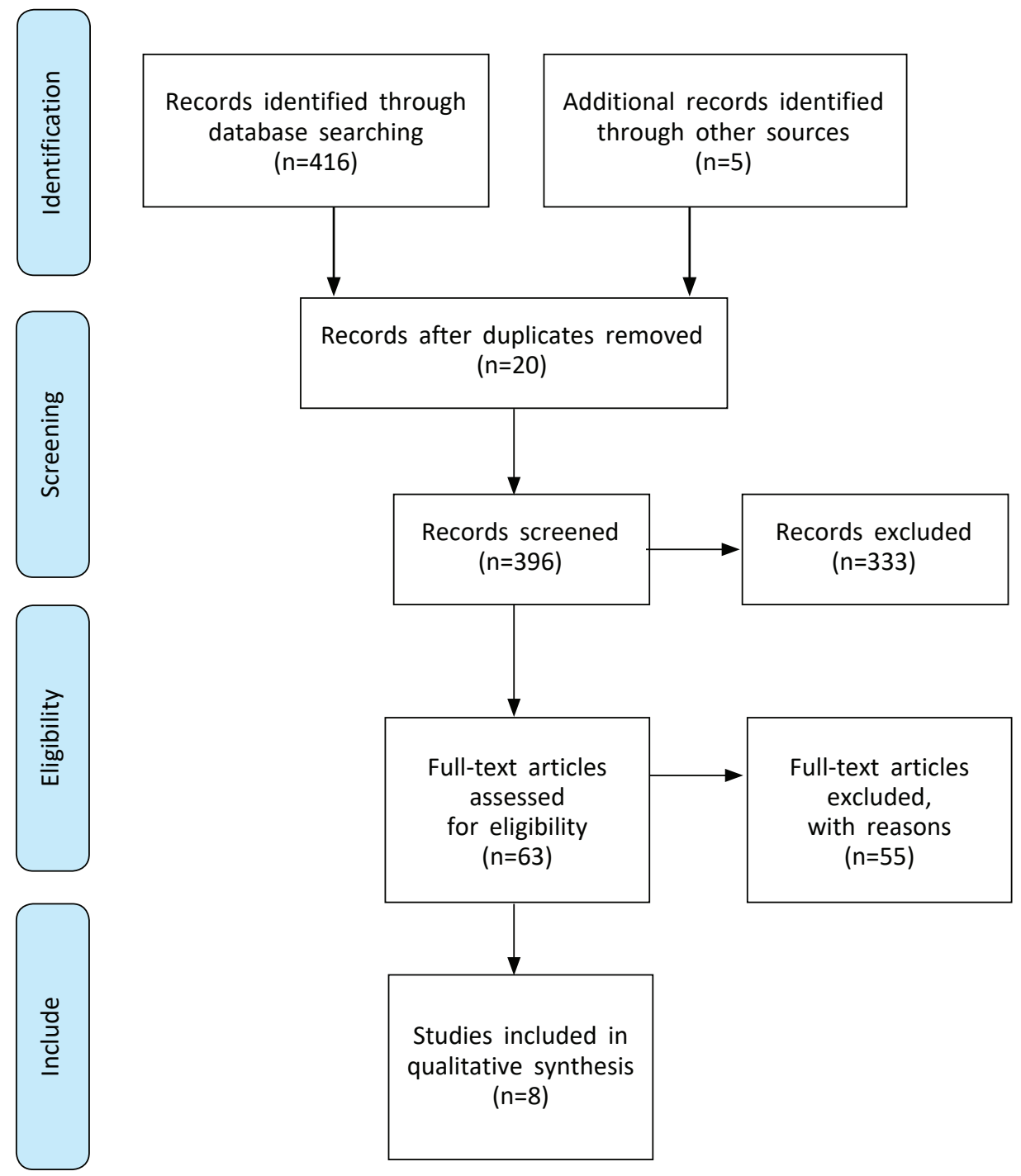

Figure 1. PRISMA literature searched flow diagram

Figure 2. Tumor microenvironment. Tumor-associated materials, such as circulating tumor cells and circulating tumor DNA (as indicated), can be released into circulation. These components carry genetic information about primary tumors from apoptosis,

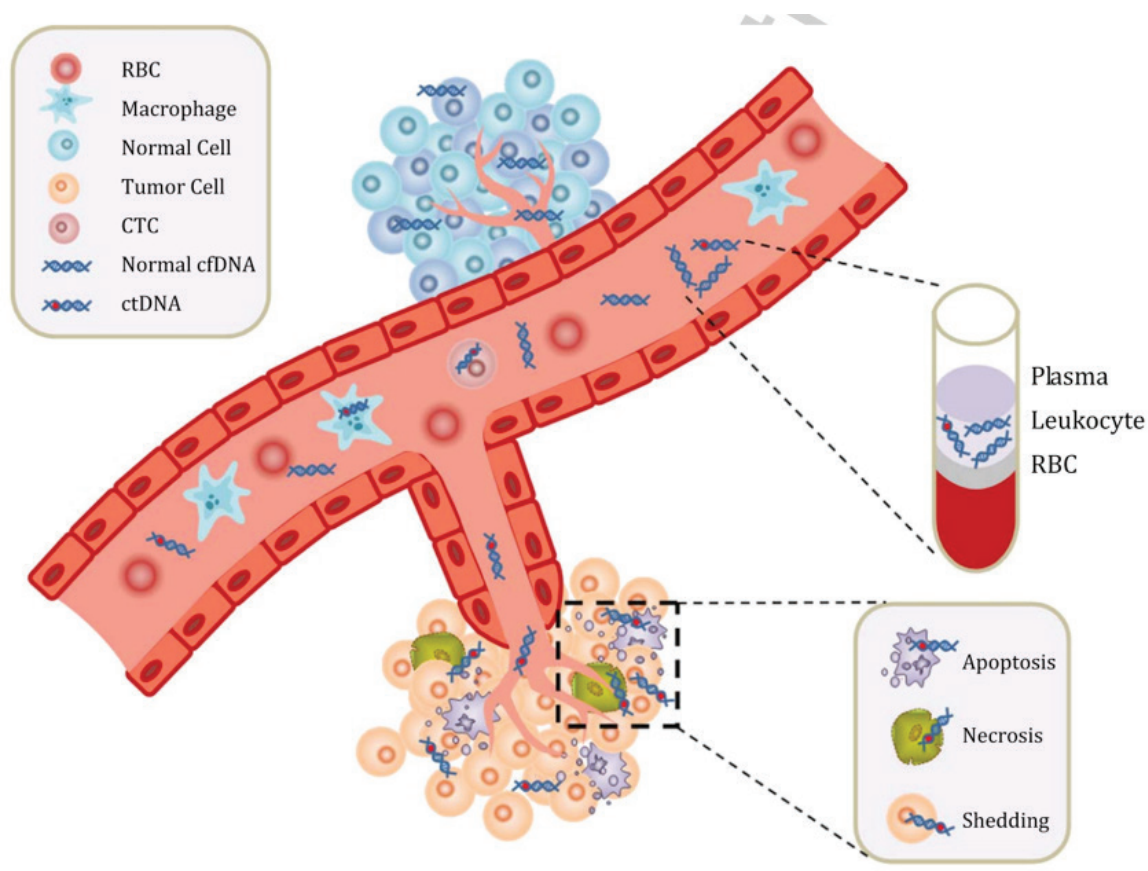
necrosis, and shedding process [3]. 
Table 3. Characteristics of the studies

\begin{tabular}{|c|c|c|c|c|c|}
\hline $\begin{array}{l}\text { Author, } \\
\text { years, } \\
\text { country }\end{array}$ & Subjects & $\begin{array}{l}\text { Method of } \\
\text { Detection }\end{array}$ & Mutation & NOQ & Outcome of interest \\
\hline $\begin{array}{l}\text { Shiwei, } \\
\text { 2020, } \\
\text { China [23] }\end{array}$ & $\begin{array}{l}130 \text { patients in } \\
\text { the discovery } \\
\text { cohort and } 47 \\
\text { patients in the } \\
\text { validation cohort: } \\
150 \text { patients with } \\
\text { stage I-Il disease. }\end{array}$ & $\begin{array}{l}\text { Firefly NGS-based } \\
\text { assessment } \\
\text { ddPCR. }\end{array}$ & $\begin{array}{l}\text { 50-panel genes } \\
\text { Six KRAS mutations } \\
\text { G12D } \\
\text { G12V } \\
\text { G12R } \\
\text { G12C } \\
\text { G12A } \\
\text { G12S }\end{array}$ & Good & $\begin{array}{l}33 \text { PDAC associated gene mutations } \\
\text { were found in } 43 \text { patients ( } 38.03 \%) \text {. } \\
\text { KRAS is the most frequent mutation } \\
(23 \%) \text { with the KRAS G12D found to } \\
\text { be the most common finding. } \\
\text { Firefly NGS has a comparable } \\
\text { concordance rate with ddPCR, } \\
\text { but it provided more KRAS mutation } \\
\text { landscape. } \\
25 \text { patients with KRAS mutation } \\
\text { detected in ctDNA, also harbored } \\
\text { KRAS mutation in a tissue sample } \\
\text { (96.1\%) }\end{array}$ \\
\hline $\begin{array}{l}\text { Groot, } \\
\text { 2019, USA } \\
{[22]}\end{array}$ & $\begin{array}{l}59 \text { patients with } \\
\text { localized PDAC. }\end{array}$ & ddPCR & $\begin{array}{l}\text { Four KRAS mutations } \\
\text { G12V } \\
\text { G12D } \\
\text { G12R } \\
\text { Q61H }\end{array}$ & Good & $\begin{array}{l}49 \% \text { of patients had KRAS mutation } \\
\text { in ctDNA. } \\
45 \% \text { of patients were positive for } \\
\text { G12V mutation. } \\
29 \text { out of } 59 \text { patients ( } 49 \% \text { ) with } \\
\text { detected KRAS mutation in tumor, } \\
\text { also had KRAS mutation in ctDNA. }\end{array}$ \\
\hline $\begin{array}{l}\text { Patel, } \\
\text { 2019, } \\
\text { USA [7] }\end{array}$ & $\begin{array}{l}112 \text { patients with } \\
18 \text { patients with } \\
\text { surgically } \\
\text { resectable disease. }\end{array}$ & NGS & 54-72 panel genes & Good & $\begin{array}{l}5 \text { out of } 10 \text { preoperative cases had } \\
\text { detectable ctDNA, with median } \\
\text { ctDNa range from } 0 \text { to } 0.62 \text {. } \\
\text { The most common alteration is TP53 } \\
\text { ( } 46 \% \text { ), followed by KRAs ( } 44 \%) \text {. } \\
\text { The concordance rate for KRAs } \\
\text { between tissue and ctDNA is } 52 \% \text {. }\end{array}$ \\
\hline $\begin{array}{l}\text { Nakano, } \\
2018, \\
\text { Japan [11] }\end{array}$ & $\begin{array}{l}45 \text { stage I-II } \\
\text { patients }\end{array}$ & qRT-PCR & KRAS mutation & Fair & $\begin{array}{l}\text { KRAS mutation was detected in } \\
11 / 45 \text { preoperative patients } \\
(24.45 \%) \text {. } \\
\text { KRAS mutations were detected in } \\
35 / 42 \text { of primary tumors }(83.3 \%) \text {. }\end{array}$ \\
\hline $\begin{array}{l}\text { Kim, } \\
2018, \\
\text { South } \\
\text { Korea [6] }\end{array}$ & $\begin{array}{l}106 \text { PDAC } \\
\text { patients: } 16 \\
\text { resectable cases }\end{array}$ & $\mathrm{ddPCR}$ & $\begin{array}{l}\text { KRAS mutations } \\
\text { G12A } \\
\text { G12C } \\
\text { G12D } \\
\text { G12S } \\
\text { G12V } \\
\text { G12D }\end{array}$ & Fair & $\begin{array}{l}\text { The concordance rate of KRAs } \\
\text { mutation between tumor and cfDNA } \\
\text { was } 76.6 \% \text {. } \\
\text { The positivity rate of KRAS mutation } \\
\text { in resectable cases was } 68.6 \% \text {. }\end{array}$ \\
\hline $\begin{array}{l}\text { Cohen, } \\
2017 \\
\text { USA }\end{array}$ & $\begin{array}{l}221 \text { resectable } \\
\text { PDAC patients } \\
182 \text { control }\end{array}$ & $\begin{array}{l}\text { PCR based assay } \\
\text { is known as Safe } \\
\text { Sequencing } \\
\text { System (Safe-SeqS) }\end{array}$ & KRAS and TP53 & Good & $\begin{array}{l}32 \% \text { of patients harbor KRAS } \\
\text { mutation in ctDNA with a } 100 \% \\
\text { concordance rate with primary } \\
\text { tumor. } \\
60 \% \text { sensitivity from a combination } \\
\text { of ctDNA and CA } 19-9\end{array}$ \\
\hline $\begin{array}{l}\text { Hadano, } \\
\text { 2016, } \\
\text { Japan [4] }\end{array}$ & $\begin{array}{l}105 \text { PDAC } \\
\text { patients: } 84 \text { stage } \\
\text { I-II patients }\end{array}$ & $\mathrm{ddPCR}$ & $\begin{array}{l}\text { KRAS mutations G12D } \\
\text { G12V } \\
\text { G12R }\end{array}$ & Fair & $\begin{array}{l}25 / 84 \text { patients had KRAS mutation } \\
\text { in ctDNA. } \\
100 \% \text { concordance rate between } \\
\text { ctDNA and primary tumor. }\end{array}$ \\
\hline $\begin{array}{l}\text { Takai, } \\
\text { 2015, } \\
\text { Japan [10] }\end{array}$ & $\begin{array}{l}259 \text { patients: } 78 \\
\text { stage I-II patients }\end{array}$ & ddPCR & $\begin{array}{l}\text { KRAS mutations G12D } \\
\text { G12V } \\
\text { G12R } \\
\text { G13D }\end{array}$ & Good & $\begin{array}{l}8 \text { patients had detectable KRAS } \\
\text { mutation in ctDNA. }\end{array}$ \\
\hline
\end{tabular}

Abbreviations: NOQ: Newcastle-Ottawa validity test; NGS: next-generation sequencing; ddPCR: digital droplet polymerase chain reaction; ctDNA: circulating tumor DNA; CA 19-9: carbohydrate antigen 19-9. 
despite the limited number of KRAS mutant positive ctDNA in the early stage $[5,10,11]$, Hadano et al. [4] revealed that all localized cases with KRAS mutated ctDNA also harbor KRAS mutation in their primary tumors (100\% concordance), supporting the notion that at a certain level, primary tumor releases DNA containing a specific mutation. It is also worth mentioning that variability in detection technology across studies, low DNA concentration in the plasma, and tumor heterogeneity-different molecular properties across tumor region-may foster the inconsistency in concordance rate. Therefore, a validation study using more stringent criteria involving early-stage PDAC cases with more advanced techniques targeting KRAS mutation is required.

\section{High Accuracy}

Circulating tumor DNA provides relatively high accuracy. Many reports have drawn this conclusion with varied numbers $[8,12,13]$. Firstly, KRAS detection via ctDNA achieved sensitivity and specificity of $95.7 \%$ and $100 \%$, respectively [8]. Further investigation within the same study showed a correlation between KRAS mutation and different clinical stages $(p<0.05)$. Subsequently, combining KRAS mutation with a standard marker such as carbohydrate antigen 19-9 (CA19-9) showed a consistent detection rate in all stages [13]. With a sensitivity of $64 \%-78 \%$ and a specificity of $91 \%-99.5 \%$, this combination was also superior to a single marker assay $[5,14]$. Furthermore, another strong point of ctDNA was its ability to distinguish the preinvasive lesion (IPMN) from healthy control with comparable sensitivity and specificity $(80.95 \%$ and $84.21 \%$, respectively) [12]. However, it should be interpreted cautiously as stage I and II cases in the abovementioned studies showed less or undetectable KRAS mutation in their ctDNA [13]. Also, one study enrolled only two early-stage patients [8]. Nevertheless, these findings support the relevance of ctDNA measurement at any stage of the disease and establish the fundamental reasoning to promote the clinical translation of ctDNA into practice.

\section{Easy to Obtain}

Liquid biopsy is a popular name for blood collection and ctDNA testing. In the clinical setting, the liquid biopsy provides benefit since routine biopsy procedures, such as endoscopic ultrasound fine-needle aspiration (EUS-FNA), impose certain limitations. EUS-FNA requires sedation, which can put a patient in anesthesia-related adverse events [14]. At some conditions, a tumor might be inaccessible and, thus, incapable of being extracted and examined [15]. Even so, the risk of tumor seeding might be increased during the procedure [16]. In contrast, drawing simple blood work is a routine procedure in clinical practice. Since it is an easy to access way, a serial measurement for an inconclusive result is achievable. Nevertheless, one aspect to date for ctDNA measurement is the demand for high technical expertise and higher cost. Eventually, one study already covered the issue of high cost by proposing digital droplet polymerase chain reaction (ddPCR), which has the lowest cost than any other ctDNA detection platform (€39-€298 per sample) [17]. However, this finding should be validated in non-metastatic cases, which inevitably pose more technical difficulties.

\section{Challenges to be Addressed}

Measurement of ctDNA in early-stage PDAC has become a major challenge for researchers. Firstly, the early-stage disease has a lower quantity of DNA in circulation than the metastatic disease $(15 \mathrm{ng} / \mathrm{ml}$ vs. $22.6 \mathrm{ng} / \mathrm{ml}$ ) [18]. In other words, a larger amount of ctDNA is associated with a greater tumor burden in the advanced stage. Most studies overcome this problem using ddPCR, which provides more wells to improve detection $[4,8,13]$. Secondly, the actual level of ctDNA might be confounded by another circulating free DNA (cfDNA) from normal cells. For instance, in ovarian cancer, cfDNA from normal cells makes up about 80$90 \%$ of all DNA in the blood [19]. Furthermore, a certain condition such as high-intensity exercise significantly increases cfDNA due to reactive oxygen species (ROS) production [20]. Fortunately, the current method, such as fragment analysis, allowed the separation of ctDNA from normal cfDNA based on the fragmentation pattern [21]. Finally, despite the promising accuracy, researchers have not reached a consensus on the target mutation of ctDNA. Specific to PDAC, the two most mutated genes, KRAS and TP53, have been identified in ctDNA [7]. Nevertheless, other works of literature also detected multiple genetic alterations with comparable accuracies $[8,17]$. Therefore, it is reasonable to measure the KRAS and TP53 genes even though they still require a costbenefit analysis and validation in larger samples.

\section{CONCLUSIONS}

ctDNA undoubtedly promotes a feasible method for the early detection of PDAC. ctDNA, as a naturally released genetic information from the tumor in the blood, has a high concordance rate, reflecting the primary tumor. It shows high accuracies and easy sample collection. Nonetheless, improvements are still required to circumvent technical issues for the near future implementation. 


\section{DECLARATIONS}

\section{Ethics approval and consent to participate}

Ethics approval for this review is not required.

\section{Competing of Interest}

The authors declare no competing interest in this study.

\section{REFERENCES}

1. Bray F, Ferlay J, Soerjomataram I, et al. Global cancer statistics 2018: GLOBOCAN estimates of incidence and mortality worldwide for 36 cancers in 185 countries. CA Cancer J Clin. 2018;68(6):394-424.

2. Werner J, Combs S, Springfeld C, et al. Advancedstage pancreatic cancer: therapy options. Nat Rev Clin Oncol. 2013;10(6):323-33.

3. Hahn AW, Nussenzveig RH, Maughan BL, Agarwal N. Cell-free circulating tumor DNA (ctDNA) in metastatic Renal Cell Carcinoma (mRCC): current knowledge and potential uses. Kidney Cancer. 2019;3(1):7-13.

4. Hadano N, Murakami Y, Uemura K, et al. Prognostic value of circulating tumour DNA in patients undergoing curative resection for pancreatic cancer. Br J Cancer. 2016;115(1):59-65.

5. Cohen J, Javed A, Thoburn C, et al. Combined circulating tumor DNA and protein biomarker-based liquid biopsy for the earlier detection of pancreatic cancers. Proc Natl Acad Sci. 2017;114(38):10202-207.

6. Kim MK, Woo SM, Park B, et al. Prognostic implications of multiplex detection of KRAS mutations in cell-free DNA from patients with pancreatic ductal adenocarcinoma. Clin Chem. 2018;64(4):726-34.

7. Patel H, Okamura R, Fanta P, et al. Clinical correlates of blood-derived circulating tumor DNA in pancreatic cancer. J Hematol Oncol. 2019;12(1):1-12.

8. Park G, Park J, Son D, et al. Utility of targeted deep sequencing for detecting circulating tumor DNA in pancreatic cancer patients. Sci Rep. 2018;8(1):1-10.

9. Uemura $T$, Hibi $K$, Kaneko $T$, et al. Detection of $\mathrm{K}$ - ras mutations in the plasma DNA of pancreatic cancer patients. J Gastroenterol. 2004;39(1):56-60.

10. Takai E, Totoki $Y$, Nakamura $H$, et al. Clinical utility of circulating tumor DNA for molecular assessment in pancreatic cancer. Sci Rep. 2015;5(18425):1-10.

11. Nakano $Y$, Kitago M, Matsuda S, et al. KRAS mutations in cell-free DNA from preoperative and postoperative sera as a pancreatic cancer marker: a retrospective study. Br J Cancer. 2018;118(5):662-9.
12. Berger A, Schwerdel D, Ettrich $T$, et al. Targeted deep sequencing of circulating tumor DNA in metastatic pancreatic cancer. Oncotarget. 2017;9(2):2076-85.

13. Wang $Z$, Ding $X$, Zhu $H$, Wang $R$, et al. KRAS mutant allele fraction in circulating cell-free DNA correlates with clinical stage in pancreatic cancer patients. Front Oncol. 2019;9:1-8.

14. Sefrioui D, Blanchard F, Toure E, et al. Diagnostic value of CA19.9, circulating tumour DNA and circulating tumour cells in patients with solid pancreatic tumours. Br J Cancer. 2017;117(7):1017-25.

15. Marrugo-Ramírez J, Mir M, Samitier J. Blood-based cancer biomarkers in liquid biopsy: A promising noninvasive alternative to tissue biopsy. Int J Mol Sci. 2018;19(10):1-21.

16. Shyamala K, Girish H, Murgod S. Risk of tumor cell seeding through biopsy and aspiration cytology. J Int Soc Prev Community Dent. 2014;4(1):5-11.

17. Vessies D, Greuter M, Rooijen K, et al. Performance and cost comparison of circulating tumor DNA detection platforms [abstract]. In: Proceedings of the American Association for Cancer Research Annual Meeting 2019; 2019 Mar 29-Apr 3; Atlanta, GA. Philadelphia (PA): AACR; 2019 [cited 2020 Dec 2]. Available from: https://cancerres.aacrjournals.org.

18. Ako S, Nouso K, Kinugasa $\mathrm{H}$, et al. Utility of serum DNA as a marker for KRAS mutations in pancreatic cancer tissue. Pancreatology. 2017;17(2):285-90.

19. Harris F, Kovtun I, Smadbeck J, et al. Quantification of Somatic Chromosomal Rearrangements in Circulating Cell-Free DNA from Ovarian Cancers. Sci Rep. 2016;6(1):1-9.

20. Stawski R, Walczak K, Perdas E, et al. Decreased integrity of exercise-induced plasma cell free nuclear DNA - negative association with the increased oxidants production by circulating phagocytes. Sci Rep. 2019;9(1):1-11.

21. Mouliere F, Chandrananda D, Piskorz A, et al. Enhanced detection of circulating tumor DNA by fragment size analysis. Sci Transl Med. 2018;10(466):1-14.

22. Groot V, Mosier S, Javed A, et al. Circulating Tumor DNA as a Clinical Test in Resected Pancreatic Cancer. Clin Cancer Res. 2019;25:4973-84.

23. Shiwei $G$, Xiaohan $S$, Jing $S$, et al. Preoperative detection of KRAS G12mutation in ctDNA is a powerful predictor of2020r early recurrence of resectable PDAC patients. $\mathrm{Br} J$ Cancer. 2020;122(6):857-67. 